\title{
Molecular identification of peste des petits ruminants virus in wild goat and domestic small ruminants by real-time -PCR technique in Erbil-Iraq
}

\author{
E.P. Candlan, F.P. Khoran* and L. Hana \\ Directorate of the Central Veterinary Laboratory in Kurdistan Region, Iraq \\ *Corresponding Author: E mail: elhampat@yahoo.com \\ fasialpolis@yahoo.com
}

(Received March 12, 2017; Accepted May 18, 2017)

\begin{abstract}
In July 2010 outbreak was occurred in wild goat in Barzan, Sherwin mizzen and Mergasur in Kurdistan Region- Iraq. There were over 2700 deaths (both young and adult) during the period of July 2010 to October 2011. Based on the clinical signs and post-mortem findings, the involvement of peste des petits ruminants virus (PPRV) was suspected. This was confirmed by Real Time PCR technique using TaqMan ${ }^{\mathbb{B}}$ probes for the detection of Peste des petits ruminants. The results of Real-Time PCR for the 9 sample taken from 9 Wild goat there are 6 sample positive and 3 sample negative and 76 sample from domestic ruminants (sheep and goat) 63 samples was negative for PPR. This result confirms the diagnosis domestic ruminants in the region are routinely vaccinated with an attenuated vaccine based on the 'Nigeria/75/1' strain of PPRV.
\end{abstract}

Keywords: Pestes des petit ruminants, RNA, Real-Time PCR, wild goat Available online at http://www.vetmedmosul.org/ijvs

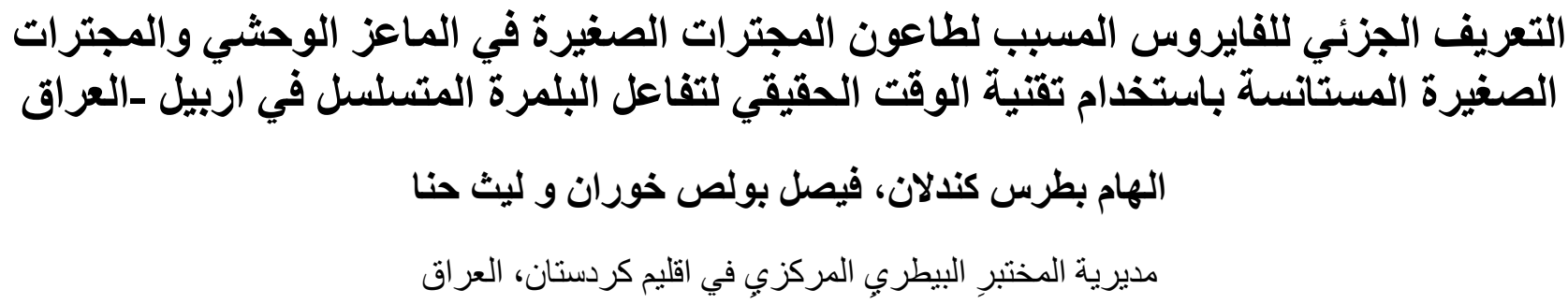

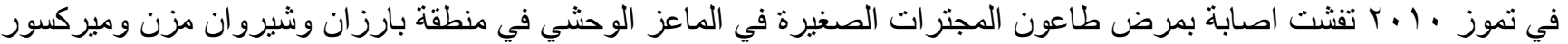

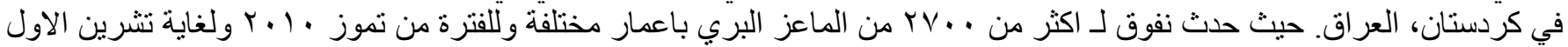

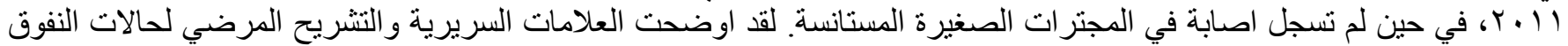
بالاصابة بمرض طاعون المجنرات الصغيرة وقد تم توثيق الاصنابة بواسطة تقنية الوقت الحقيقي لتفاعل البلمرة المتسلسل باستخدام TaqMan probes

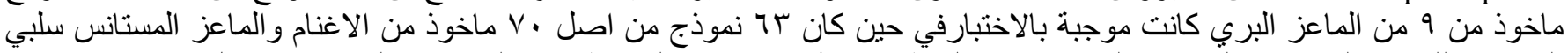

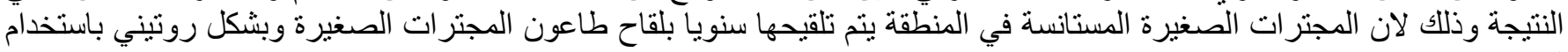

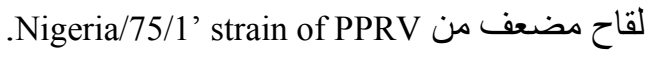

\section{Introduction}

Among domesticated animals, peste des petits ruminants (PPR) is primarily a disease of goats and sheep. It is an acute, highly contagious viral disease of sheep, goats, and wild ruminants have varying degrees of morbidity and mortality in susceptible animals (1-3). Peste des petits ruminant virus (PPRV), a morbilli virus in the Paramyxoviridae, is a linear, negative polarized, singlestranded, and unsegmented RNA virus. It is related to 
rinderpest virus and another five morbilli viruses (canine distemper, measles, dolphin distemper, phocine distemper, and porpoise distemper viruses) depending on its biological and antigenic properties $(4,5)$.

The virus is predominantly transmitted by oral, nasal, and conjunctiva secretions and stool of the infected animals which contain high concentrations of virus (2). The virus is highly contagious and easily transmitted by direct contact between the secretions and/or excretions of infected animals and nearby healthy animals (6).

Virulence appears vary from strain to strain, although there is only one serotype, and the symptoms of disease are often confused with, and exacerbated by secondary infections making the disease a difficult disease to characterize, diagnose and treatment (7). Differential diagnosis including pasteurellosis, contagious ecthyma, contagious caprine pleuropneumonia (CCPP), blue tongue (BTV), heart water, coccidiosis, mineral poisoning and foot-and mouth disease. PPRV is sometimes referred to as a more serious disease of goats than sheep, however, reports detailing an increased susceptibility of sheep populations, goat populations and outbreaks affecting sheep and goat populations have been equally reported (8-11).

The first deaths among wild goats around Davare Barzan, north of Kurdistan Iraq were reported in 12-july 2010. Based on the clinical signs and post-mortem findings, PPR was suspected. In December 2010, we confirm the diseases at Directorate of Central Veterinary Laboratory in Kurdistan Region -Iraq, where PPRV genome was detected by Real-Time-PCR in six clinically suspected wild goats.

The first report of active PPRV infection in Kurdistan Region- Iraq of wild goat (12). The aim of this study are confirm the diagnosis by collecting samples from different area from kudrstain region by Real time PCR.

\section{Materials and methods}

Samples were taken from 9 clinically suspected wild goats (Swab from mouth) from (Barzan, Sherwin mizzen and Mergasur) as well as samples taken from 76 domestic ruminates (sheep and goats) in the Erbil Region. All these samples were submitted to Directorate of Central Veterinary Laboratory in Kurdistan Region -Iraq. Between 20 December 2010 to 24 October 2011 we test 9 samples from wild goat for PPRV and we test 76 sample from domestic ruminants in Erbil for PPRV.

The study was done in Erbil- kurdestain region, and the samples were collected during the period from 20-12-2010 to 24-10-2011 from wild goat and domestic ruminants in Erbil- Kurdistan Region -Iraq.

Swab samples are collected in Erbil- Kurdistan Region -Iraq from wild goat and domestic ruminants (9 samples) for wild goat and (76 sample) from domestic ruminants.
Samples of swab are taken from mouth lesions of wild goat and domestic ruminants putting these swab in a clean sterile containers. All the samples are stored at $(-120){ }^{\circ} \mathrm{C}$ until the extraction method.

RNA extraction: All samples were extracted by using RNeasy_ Mini Kit (Qiagen, Hilden, Germany). The extraction had done according to the protocol, and finally the extracted RNA had stored at $(-120){ }^{\circ} \mathrm{C}$ until the amplification procedure.

Amplification of samples: The extracted samples are thawed well at room temperature, then used the kit TagMan ${ }^{\circledR}$ probes (TagVet ${ }^{\mathrm{TM}}$ Peste des Petits Ruminants Virus) Ref: PPRP/50 is from Laboratoire Service international (LSI) France for the running of the samples.

\section{Results}

Table 1 show the area were the samples collected and number of animals and positive sample. The results of Real-Time PCR for the 9 sample of 9 from wild goat there are 6 samples positive and 3 sample negative but the 76 sample from 76 domestic ruminants (sheep and goat) in Erbil Governorate 13 sample positive and 63 sample negative for PPR submitted animal samples are given in Table 1. All wild goats were positive for PPRV that had not yet been vaccinated. All domestic ruminants were positive for PPRV that had not yet been vaccinated. Figure 1 show the positive sample compare with control, while figure 2 show the positive of internal positive control(1PC) of the samples.

\section{Discussion}

In the present study attempts were made to detect Peste des petits ruminants from wild goat in Erbil Governorate and this is the first study to detect Peste des petits ruminants virus from wild goat in Kurdistan region. Inspire of the most test samples are positive Peste des petits ruminants, this virus may be found in our country because the long borders countries had diagnose this virus infection in there countries had diagnose this viral infection and especially the long border and a large trade relation with Turkey (12). It was observed that the domestic sheep and goats of the near villages come into contact with these wild animals when grazing and at common water sources.

The disease in Kurdistan Iraq initially showed as sporadic dead animals followed by both dead and diseased animals near the water sources in the area. Vaccinating the domestic herds of sheep and goats and disinfection of the common water sources in the villages surrounding the Turkey border resulted in the control of disease (3). Unvaccinated young stock is probably protected by passively transferred maternal $(4-11,13)$. 
Table 1: show the area collection, Number of sample collect and positive samples

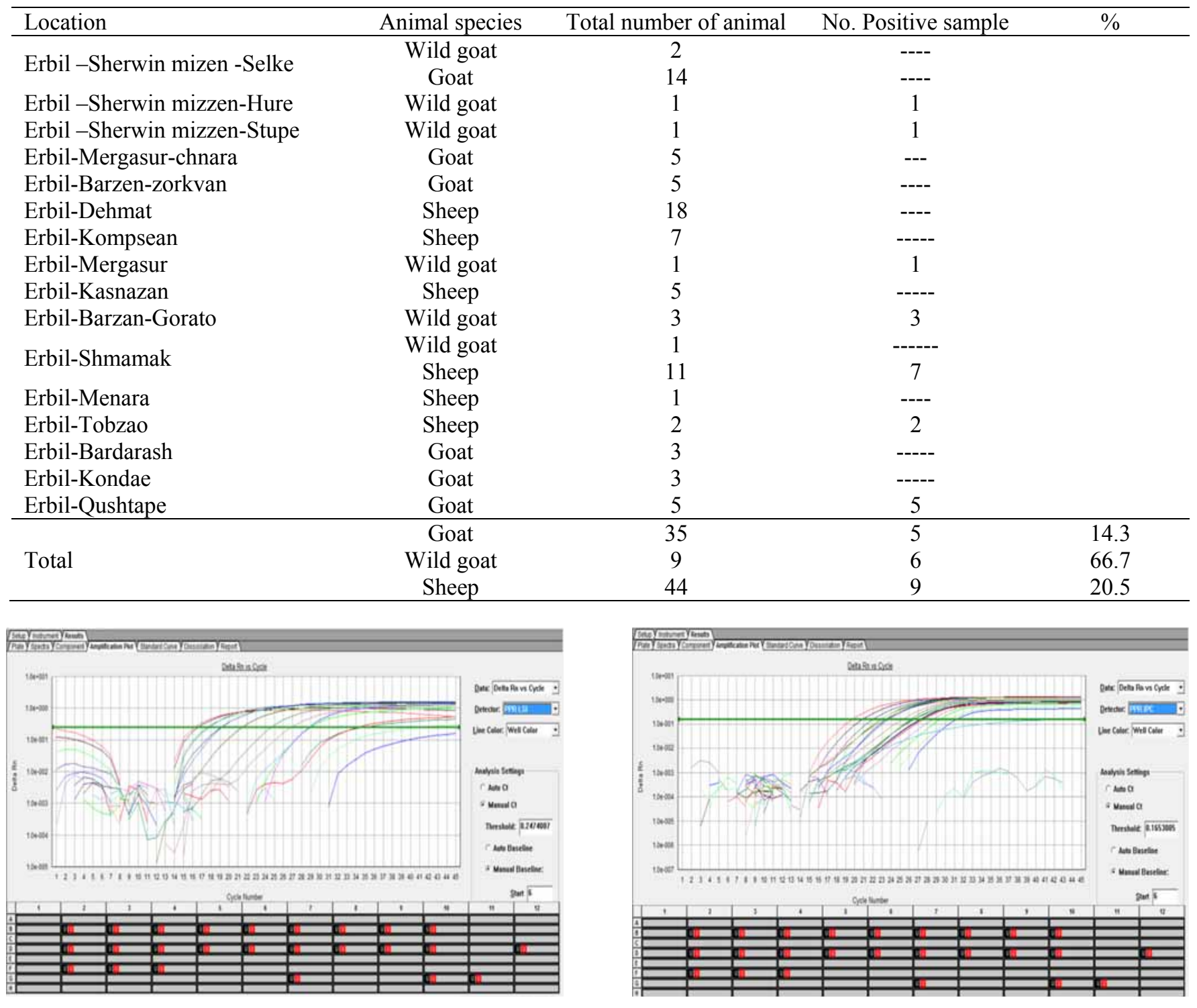

Figure 1: show Positive of the samples compare with control.

The field data and laboratory results implicate PPR in the observed mass fatalities in wild goats in Kurdistan Iraq. Based on the sequencing results, the most likely cause is a PPRV field strain that has obviously been circulating in the region for more than 10 years. The affected area is close to the Turkey border, where PPRV is known to be endemic (5). There is no evidence for a transmission of the modified-live vaccine strain from vaccinated domestic animals to wild goats. During the outbreak in wild goats, no disease was reported in domestic animals.
Figure 2: show positive of internal positive control (IPC) of the samples.

Antibodies it is recommended to continue with the vaccination campaign. On the other hand, the use of force to keep wild goats away from domestic flocks is unjustified and would further endanger the survival of the species (12).

\section{References}

1. Taylor WP. The distribution and epidemiology of pestedespetits ruminants. Prev Vet Med. 1984;2:157-166.

2. Abuelzein FM, HousawiT, Ousawi Y, Bashareek A, GameelA, ALAfaleqAI, Andersone EC. Severe PPR infection in gazelles kept under 
semi-free range conditions in Saudi Arabia. J Vet Microbiol. 2004;51:68-71.

3. Albayrak H, Alkan F. PPR virus infection on sheep in blacksearegion of Turkey: Epidemiology and diagnosis by RT-PCR and virus isolation. Vet Res Commun. 2009;33: 241-249.

4. Gibbs EP, Taylor JWP, Lawman MJP, Bryant J. Classification of peste des petits ruminants virus as the fourth member of thegenus morbillivirus. Int Virol. 1979;11:268-274.

5. Barrett $\mathrm{T}$, Morbilli virus infections with special emphasis on morbilli virus of carnivores. Vet Microbiol. 1999;69:3-13.

6. Banyard AC, Parida S, Batten C, Oura C, Kwiatek O, Libeau G. Global distribution of peste des petits ruminants virus and prospects for improveddiagnosis and control. J Gen Virol. 2010;91:2885-2897.

7. Ezeibe MCO, Okoroafor ON, Ngene AA, EzeJI,Eze IC, Ugonabo JAC. Persistent detection of peste de petits ruminants antigen in the faeces of recovered goats. Trop Anim Health Prod. 2008;40:517-519.
8. Couacy-Hymann E, Bodjo C, DanhoT, Libeau G, Diallo A. Surveillance of wildlife as a tool for monitoring rinderpest and peste des petitsruminants in West Africa. Rev Sci Tech. 2005;24:869-877.

9. Chauhan H, Chandel B, Kher H, Dadawala A, Agrawal S. Peste despetits ruminants infection in animals. Vet World. 2009;2:150-155.

10. Roeder PL, Abraham G, Kenfe G. Barrett, T. Peste des petits ruminants in Ethiopian goats. Trop Anim Health Prod.1994;26:69-73.

11. Singh D, Malik YPS, Chandrasekhar KM. Design and evaluation of gene primers for detection and characterization of peste des petitsruminants (PPR) virus from central India. Indian $\mathrm{J}$ Virol. 2009;20:47-47.

12. Hoffmann H, Wiesner J, Maltzan R, Mustefa M, Schbaumer FA, Arif M. Fatalities in wild goats in Kurdistan associated with Peste Des Petits ruminants virus. Blackwell Verlag GmbH. Transboun-dary and Emerging Diseases. 2012;pp.173-176.

13. Taylor WP, Abegunde A. The isolation of peste des petits ruminantsvirus from Nigerian sheep and goats. Res Vet Sci. 1979;26:94-96. 